Македон Г. М., к.е.н., доцент

Відокремлений підрозділ

Національного університету біоресурсів

і природокористування Украӥни "Ніжинський агротехнічний інститут» м. Ніжин, Чернігівська область, Україна

DOI: https://doi.org/10.30525/978-9934-26-028-5-44

\title{
СПОЖИВЧІ НАСТРОЇ НАСЕЛЕННЯ ПІД ЧАС КОРОНАВІРУСНОЇ КРИЗИ
}

Економіка - це інфраструктура, що забезпечує процеси виробництва, розподілу та споживання матеріальних благ та підтримує відповідні соціальні відносини. Розуміння економічних процесів неможливо без аналізу споживчих настроїв $\mathrm{i}$ економічних відносин. Споживачі забезпечують основну масу попиту на товари і послуги. I саме споживчі витрати є однією 3 тих категорій, що зазнають найбільшого спаду під час типової рецесії.

Починаючи, з березня 2020 року Україна ввела карантинні обмеження, що підвищили рівень безробіття 3 8,5\% у січня 2020 року до 9,3\% у вересні 2020 року [2]. При чому найбільш відчутними зміни були у вікових групах15-24 роки (на 24\%) i 40-49 років (на 16\%). Відповідно змінили формат роботи або взагалі перестали працювати на тривалий період багато закладів сфери послуг.

Порівнюючи кінцеві споживчі витрати домашніх господарств у III кварталі 2019 і 2020 років відмічаємо, що структура змінилася. Зокрема збільшилася частка витрат на продукти харчування та оплату комунальних послуг, у той же час зменшилася частка витрат на транспорт, ресторани та готелі, відпочинок та культуру. Відповідно до класичного закону Енгеля це $€$ одним 3 головних індикаторів зниження купівельної спроможності населення та зростання рівня бідності. 
За прогнозами Світового банку у 2020 світове ВВП впаде на 5,2\%. Для України прогнози гірші - 4-8\% падіння за різними оцінками. Ймовірно, що таке різке падіння негативно позначиться на доходах українців. Тут важливо враховувати структуру падіння. Передусім постраждають галузі, які не працюють чи обмежено працюють через карантинні заходи туристична, транспортна та частково торговельна. Тому падіння ВВП нерівномірно вплине на українців: більше на тих, хто працює у цих галузях та менше на тих, кого карантин менше зачепив. Крім того розшарованість між категоріями населення мала тренд до зростання протягом останніх років (рис. 1).

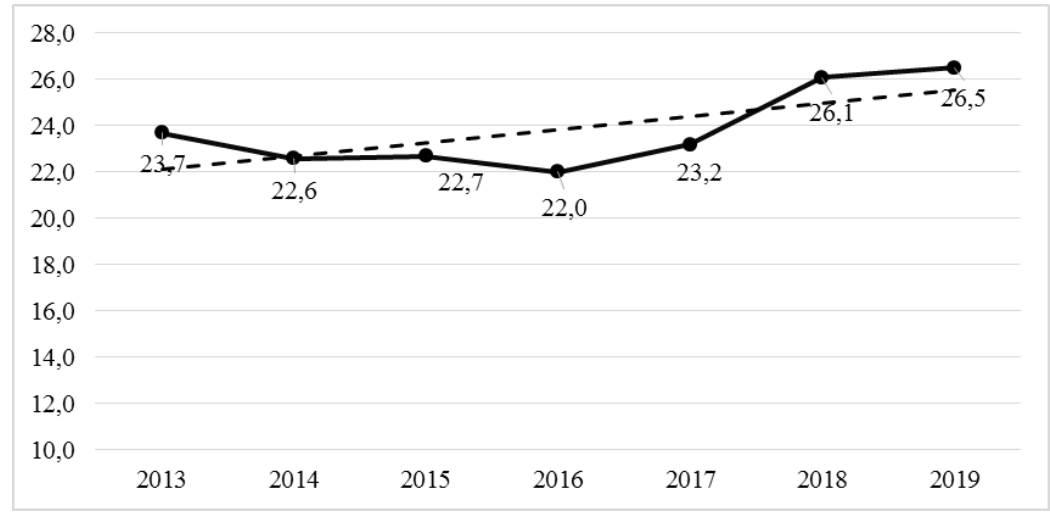

Рис. 1. Динаміка індексу Джині населення Україні, 2013-2019 pp.

Джерело: сформовано на основі [1]

Падіння споживчих витрат стало ключовим фактором різкого зниження світового ВВП на 5,7\% у ІІ кварталі 2020 року. У травні та червні зростання виявилося жвавішим, ніж очікувалося, роздрібні продажі перевищили допандемічні рівні. Однак нові спалахи пандемії припинили ріст споживання розвинених економік у липні-серпні.

Роздрібні торгівля у березні-травні обвалилася на глобальному рівні, в тому числі і в Україні, Паралельно з тим саме це стало потужним поштовхом для розвитку інтернет-торгівлі. Якщо ж 
говорити про сам обсяг витрат, то у III кварталі 2020 року він зріз на 3,5\%, порівняно з відповідним кварталом минулого року при річному рівні інфляції-25,8\%.

Індекс споживчих настроїв в Україні визначають на підставі вибіркового обстеження домашніх господарств країни за даними дослідження Info Sapiens «Споживчі настрої в Україні», що здійснюється за фінансової підтримки Dragon Capital. У листопаді 2020 року Індекс споживчих настроїв (ICH) склав 65,7 п., що на 3,3 п. вище, ніж у жовтні. Найбільш суттєвих змін зазнав Індекс доцільності робити великі покупки - він зріс на 10,2 п. Порівняно з 2020 роком значення індексу є суттєво нижчими - в середньому на 20-25 п. Мінімумами 2020 року стали квітень (рис. 2), на який припав розпал першої хвилі карантину і розуміння довгостроковості обмежувальних заходів та закінчення року (жовтень, листопад), враховуючи економічну ситуацію та прогнозу ВВП і інфляції. У загальному, за весь період розрахунків індексу (20 років) в Україні, його значення ніколи не перетнули позначку 100, яка позначає ситуацію, коли частки позитивних і негативних оцінок однакові [3].

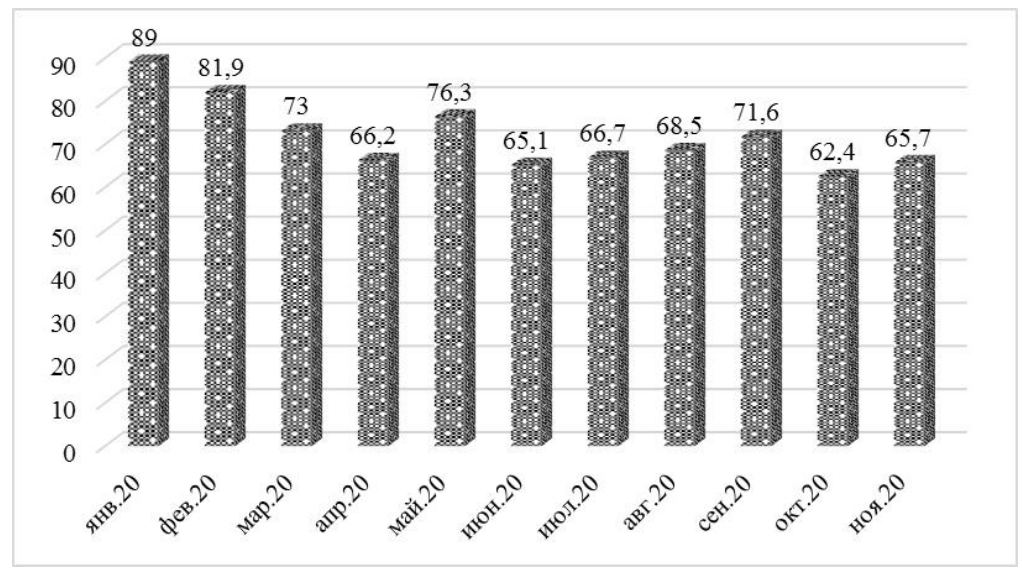

Рис. 2. Динаміка Індексу споживчих настроїв серед домогосподарств України, 2020 рік

Джерело: сформовано на основі [3] 
Коронавірусна економічна криза 2020 року вплинула на споживчі настрої населення. Та незважаючи на істотні економічні втрати населення як і раніше орієнтоване на споживання товарів $\mathrm{i}$ послуг. Споживча активність в Україні на основних ринках продовжує зростати, що дає підстави розраховувати на відновлення економіки і їі перехід до зростання вже на початку 2021 року.

\section{Література:}

1. Витрати і ресурси домогосподарств України у 2019 році статистичний збірник. Частина I. Київ. 2020. 450 с.

2. Державний служба статистики України. URL: http://www.ukrstat.gov.ua/ (дата звернення: 03.01.2020).

3. Дослідницька агенція «Info Sapiens». URL: https://sapiens.com.ua/ua/index (дата звернення: 04.01.2020). 